This item was submitted to Loughborough's Research Repository by the author.

Items in Figshare are protected by copyright, with all rights reserved, unless otherwise indicated.

\title{
Beyond the curriculum: integrating sustainability into business schools
}

PLEASE CITE THE PUBLISHED VERSION

http://dx.doi.org/10.1007/s10551-015-2896-6

\section{PUBLISHER}

(C) Springer Science+Business Media

\section{VERSION}

AM (Accepted Manuscript)

\section{PUBLISHER STATEMENT}

This work is made available according to the conditions of the Creative Commons Attribution-NonCommercialNoDerivatives 4.0 International (CC BY-NC-ND 4.0) licence. Full details of this licence are available at: https://creativecommons.org/licenses/by-nc-nd/4.0/

\section{LICENCE}

CC BY-NC-ND 4.0

\section{REPOSITORY RECORD}

Painter-Morland, Mollie, Ehsan Sabet, Petra Molthan-Hill, Helen Goworek, and Sander de Leeuw. 2019. "Beyond the Curriculum: Integrating Sustainability into Business Schools". figshare. https://hdl.handle.net/2134/21318. 


\title{
Beyond the curriculum: Integrating sustainability into business schools
}

\begin{abstract}
This paper evaluates the ways in which European business schools are implementing sustainability and ethics into their curricula. Drawing on data gathered by a recent large study that the Academy of Business Society conducted in cooperation with EFMD, we map the approaches that schools are currently employing by drawing on and expanding Rusinko’s (Acad Manag Learn Educ 9(3):507-519, 2010) and Godemann et al.' s (Approaches to changing the curriculum 2011) matrices of integrating sustainability in business and management schools. We show that most schools adopt one or more of the four approaches outlined by Godemann et al. (Approaches to changing the curriculum 2011). However, we also argue that a fifth dimension needs to be added as the existing matrices do not capture the systemic nature of such curricular initiatives and how these are influenced by internal factors within the business school and external factors beyond. We suggest calling this fifth dimension 'Systemic Institutional Integration' and demonstrate that any business school which aims to integrate sustainability further into the curricula cannot succeed without the following: (1) Systemic thinking and systemic leadership, (2) Connectedness to business, the natural environment and society and (3) Institutional capacity building. Utilising further literature and the answers provided by the deans and faculty, we discuss each factor in turn and suggest ways forward to a successful systemic institutional integration of sustainability and ethics into management education.
\end{abstract}




\section{Introduction}

Over the past decade, deans and CEOs have come to acknowledge the importance of sustainability as a strategic concern that should form part of all management education (Hommel et al, 2012). The term 'sustainability' has been long been associated with the Brundtland Commission's definition ${ }^{1}$ (1987), but it has gained momentum over the years, and is now used as an umbrella term that encompasses all the dimensions that contribute to sustainable business operations. As such, it covers organisations' social, environmental and economic performance (Kiron et al. 2012, p. 70), or in other terms, their concern for the triple bottom-line of people, planet and profit (Ten Bos and Bevan, 2011, p. 288). In this study, we follow Hommel at al (2012) in also considering ethics / governance as central to all these dimensions of corporate performance, arguing that sustainability is displayed in and through an organisation's ethics, social, governance and environmental performance (ESGE).

However, the way in which these strategic concerns should be dealt with in management education remains a matter of debate, and the extent to which Universities' schools of business and/or management schools (hereinafter referred to as business schools) have managed to integrate these issues into their institutions' curricula and operations, remains disputable. In fact, the majority of faculty members confirm the peripheral status of ethical, social, governance and environmental (ESGE) issues of organisations within management education (Hommel et al, 2012). Despite some acknowledgement of the importance of incorporating sustainability issues within the

\footnotetext{
${ }^{1}$ According to the Brundtland Commission (WECD, 1987:16), sustainable development "meets the needs of the present without compromising the ability of future generations to meet their own needs".
} 
mainstream curriculum, there seem to be real barriers to the integration of these issues in core management disciplines (Rasche et al, 2013). The prolonged economic crisis, public criticism of business schools and challenges to business school managers' leadership are viewed by Muff et al (2013) as key obstacles to implementing change in business schools.

Our goal in this paper is two-fold: In the first place, we want to see how far business schools have come in integrating sustainability into their various curricula. To do so, we will compare our empirical findings to Rusinko's (2010) and Godemann et al's (2011) matrices of integrating sustainability within management and business education. This will allow us to assess whether schools are 'Piggybacking', 'Digging deep', 'Mainstreaming' or 'Focusing' in their attempts to integrate sustainability and ethics. Secondly, we want to establish the extent of the systemic institutional integration of sustainability into business schools by critiquing the lack of systemic insight in all of these practices. To develop the criteria for this, we draw on the literature regarding the success factors in terms of systemic thinking around sustainability. We argue that the Rusinko (2010) and Godemann et al (2011) matrix should be extended to include a fifth practice, which we named 'systemic institutional integration'. The two key components of 'systemic institutional integration' are: connected leadership and capacity building across the business school. By comparing our empirical findings to our proposed key elements of this fifth practice, we hope to indicate how far schools have come in fully integrating sustainability institutionally. In order to answer these questions, we draw on data gathered from deans and faculty members of the [***removed for blind review] study. We will highlight that although there seem to be multiple activities in a variety of 
areas, displaying different approaches, few schools can really be said to have fully integrated the sustainability agenda in their curricula and within their institutional operations.

\section{Approaches to integrating sustainability within the business school curriculum}

In a seminal paper on sustainability in higher education Sterling (2004) proposes three potential levels of response by educational institutions to the challenge of teaching sustainability:

1. Educating about sustainability - an accommodative response

2. Education for sustainability - a reformative response

3. Capacity building - a transformative response

The first level is the most basic, with sustainability modules being added to the educational offer. The second level takes this further, with the institution itself being transformed by the adoption of more sustainable approaches. The third level is much more substantial, making the educational institution a place where students are transformed by the adoption of skills for sustainability (ibid.). In their Editorial for a journal Special Issue 'In Search of Sustainability in Management Education', Starik et al (2010:377) criticise the "incrementalist reform approaches that most individuals, organisations and societies have employed to address critical global sustainability issues..." and demand more transformative sustainability results in management education.

Muff et al (2013) criticise existing outcome measures for business schools and propose that their aim to be amongst the best business schools in the world should be 
revised to being the best for the world. The problem that emerges from the available models for integrating sustainability into the curriculum is that it suffers from some of the persistent problems haunting all management education, which can be described as its 'science-envy', its myopic orientation, and the existence of specific drivers such as accreditation, publishing criteria and rankings (Painter-Morland, 2015). Furthermore, Hühn (2013) has demonstrated that the MBA education fails in several ways. Firstly, students learn tools in their MBA education to solve cases, yet they do not reflect reality. They are encouraged to adopt a 'value-neutral' approach and to solve cases as facts; these are often made to fit the theory!

We believe that the most effective way to gauge a school's progress in these areas would be to employ the matrix developed by Rusinko (2010) and subsequently by Godemann et al (2011) showing the different levels of adoption of sustainability in education. According to Godemann et al (2011) there are four ways of implementing sustainability into the curriculum. They are detailed in figure 1 and explained in further detail below.

Insert Figure 1 here: Matrix to illustrate integration of sustainability (adapted by Godemann et al, 2011, based on Rusinko, 2010)

\section{Integrating sustainability into the curriculum through "Piggybacking"}

According to the first quadrant, 'Piggybacking', is the easiest way in which to implement the integration of sustainability into an existing module, such as providing an 
extra case study with a sustainable focus or inserting slides in a lecture that adds a sustainable dimension to the content provided. Lämsä et al (2008) propose a 'Piggybacking' strategy when they advocate the inclusion of visiting lectures by leading business people about CSR as a method of gaining Finnish University students' attention on this topic. The advantages of such an approach are that a wide range of students can gain an understanding of CSR and sustainability, including those who have not selected optional modules on the topic. However, a potential disadvantage is that this content may be viewed by students as supplementary, which can be exacerbated by leaving it until towards the end of a lecture or including a CSR lecture near the end of a module. Rusinko (2010) says of this type of approach that, though it can be implemented easily with few resources, it integrates sustainability into the curriculum in a non-uniform manner. It could therefore be considered to be more effective for the CSR and sustainability material to be presented as fully integrated within modules and to implicitly demonstrate its importance by prioritising it within schedules, e.g. by presenting it in the first half, rather than in the latter half of a module, if this is not to the detriment of the module topic itself. An example of 'Piggybacking' was reported by Hartman and Werhane (2009), who assessed the case of a US University MBA that offered curriculum content on Business Ethics devised by ethics specialists which allowed academics scope to adapt the content to their own subject areas, illustrating that this approach can facilitate the integration of sustainability into courses in a relatively seamless manner.

When business schools take this approach they often add subject-specific sustainability knowledge to an existing module, such as augmenting an operations module with content on Life-Cycle-Analysis. However, Truscheit and Otte (2007) have 
suggested that implementing sustainability education should not only change the content of modules or programmes but it should also teach students 'soft skills' such as teamwork or conceptualising an argument. In the same vein, Stibbe (2009:10-11) has developed the concept of 'sustainability literacy' which he uses "to indicate the skills, attitudes, competencies, dispositions and values that are necessary for surviving and thriving in the declining conditions of the world in ways which slowdown that decline as far as possible". This concept might be included when business schools use the 'Piggybacking' approach, but it is more likely to be integrated in the other three approaches. Table 1 summarizes examples and challenges \& opportunities of this approach.

\section{Insert Table 1 here: Examples, challenges and opportunities of "Piggybacking".}

\section{Integrating sustainability into the curriculum through "Digging Deep"}

Business schools adopting the next approach labelled 'Digging deep' in figure 1 might offer modules with a focus in sustainability such the optional modules in Environmental Law and Environmental Management offered to business school students in Middlesex University (Holt, 2003). In some ways this is also an uncomplicated technique for implementing sustainability, since no change in the existing structure is required. However, it can be perceived as an 'add-on', similar to adding a few sustainable tools and lectures into individual module as described above, especially if this is offered as an elective. Students might therefore gain the impression that sustainability can be conducted by some specialists but it is nothing for general managers or 'mainstream employees' to be concerned about. Consequently, Baden (2013) criticises the offer of 
optional sustainability modules, since they are unlikely to be selected by the students who need them the most. However, such a module can be useful if tools are taught in detail such as a module about Greenhouse Gas Management (Goworek and Molthan-Hill, 2013) where not every manager/employee needs to be a specialist and only a few need to be able to fully implement such a management programme. Table 2 summarizes examples and challenges \& opportunities of this approach.

\section{Insert Table 2 here: Examples, challenges and opportunities of "Digging deep".}

\section{Integrating sustainability into the curriculum by "Mainstreaming"}

In her matrix Rusinko (2010) suggested for the third approach to integrate sustainability into common core requirements. This can encompass the content of sustainability-related tools such as the Shared Value Approach from Porter and Kramer or reflexion on ethics in core modules such as marketing or economics. Birtch and Chiang (2014) have also demonstrated that mainstreaming ethics in all subjects conveys better than a single stand-alone course on ethics to students the message that ethics is considered important across the school. According to their research, integrating ethics throughout provides an ethical climate in the business school, which has a positive impact on current and future ethical behaviour of their students.

Godemann et al's (2011) discussion of the 'Mainstreaming' quadrant stressed that the integration of sustainability should go along with the emphasis on a broader crosscurricular perspective. This would also include the so-called 'soft skills' or other aspects of sustainability literacy (Stibbe 2009) as discussed above. For example, Southampton 
University adopted an inventive approach to 'Mainstreaming' by offering students placements within social enterprises or charities for a core entrepreneurship module (Baden, 2013). Even those students who did not choose the social enterprise option were exposed to the topic via the inclusion of a speaker from a social enterprise. Students consequently gained the opportunity to learn about social sustainability from direct experience, rather than from hypothetical content, following up the placement with an assignment evaluating its benefits. This creative method of incorporating sustainability into the core curriculum could be considered to bridge the gap between 'Digging deep' and 'Mainstreaming'. Table 3 summarizes examples and challenges \& opportunities of this approach.

\section{Insert Table 3 here: Examples, challenges and opportunities of "Mainstreaming".}

\section{Integrating sustainability into the curriculum by "Focusing"}

The fourth quadrant, 'Focusing', also addresses the broad curriculum, but requires new structures. This could be for example a new programme, such as the 'One Planet MBA' offered by the University of Exeter (Roome, 2005). Here the broad curriculum of an MBA is transformed by giving it a new structure in including sustainability across the whole curriculum and adding interdisciplinary perspectives. Another example could be a new module offered to all programmes at the beginning of their studies introducing sustainability principles and a general understanding of the challenges faced in this century and its implications for governments, intergovernmental organisations, science, business and the public. This approach has been adopted by Kurland et al (2010) in the 
development of an interdisciplinary undergraduate sustainability programme that included six other disciplines besides management.

At the Leuphana University in Lueneburg, Germany, transdisciplinary courses are offered not only to business students, but to students from all of the faculties. The content and the students are therefore from different disciplines and can practise in this group how to work in an interdisciplinary way. Indeed, the interdisciplinarity specified in this quadrant is a recurring theme in previous studies regarding sustainability curricula in Higher Education, as evidenced by a range of international examples. For example, Stubbs and Schapper (2011) stress the significance of interdisciplinary course content and teaching methods in underpinning effective sustainability education, alongside systems thinking. Moreover, Beijing Normal University in China and Aalborg University in Denmark added another dimension by adopting an approach that was both interdisciplinary and cross-cultural in nature when devising project-based learning about sustainability, making comparisons in this respect between the two countries (Du et al, 2013). Although Chhokar (2010) regrets the lack of interdisciplinary skills of staff and students in the case of integrating sustainability into the curriculum of Indian Universities, students may be encouraged to learn to respect and work alongside colleagues from other disciplines, rather than possessing identical skill sets. The fact that business school curricula are divided along functional lines does not further the kind of integrative perspective that is required for an understanding of sustainability issues (Currie et al, 2010). In fact, Table 4 summarises examples and challenges \& opportunities of this approach. 


\section{Insert Table 4 here: Examples, challenges and opportunities of "Focusing".}

\section{Beyond the curriculum: Systemic Institutional Integration (SII) of sustainability in business schools}

From our perspective, the various quadrants of the Godemann and Rusinko models are helpful in helping us understand HOW sustainability can be integrated, but they seem to be less helpful in understanding why there remain so many blockages that prevent successful institutional integration. We follow Burchell et al (2015) in arguing that we need to look the beyond the curriculum to judge whether change is in fact happening. It is therefore necessary to focus on the key institutional success factors that should be developed in order for students and staff to understand sustainability challenges, implement sustainability management and innovate towards sustainability.

The Cambridge Programme for Sustainability Leadership (Courtice and Van der Kamp 2013) found that within complex organisational settings, the sustainability leadership challenge includes: openness to the wider context, including the interconnectedness of global factors; the capability to employ systems thinking; and awareness of shifting societal norms. Integrating sustainability thinking into complex organisations is as much about allowing commitment to the agenda to emerge bottom-up, through all the organisation's business practices, as well as implementing it top-down, through strong leadership directives. The Cambridge study also identified four categories of sustainability leadership development - leadership engagement, employee awareness, champion empowerment, and executive development.

It is commonly agreed that systems thinking is one of the major building blocks of 
sustainable thinking (Clayton and Radcliffe, 1996; Stibbe, 2009). A holistic, systemic understanding is central to responding to the sustainability agenda (Baets and Oldenboom, 2009; Werhane and Painter-Morland, 2011). In order to facilitate change towards sustainability, we need to understand the complex nature of organisations and their internal and external environments. In a complex system, the interactions between cause and effect are dynamics and non-linear, i.e. multiple factors work together in complex ways to trigger change (Baets and Oldenboom, 2009, p. 3). Systemic thinking therefore entails an awareness of the complex interactions within and beyond an organisation, which influence its change dynamics. The question that however emerges is how such a systemic perspective is best developed.

Some important insights emerge from these studies. The first important insight relates to systemic thinking, and a broader awareness of how that which is taught relates to the world. Furthermore, it considers the business school as an open system, which influence those within it and the knowledge they generate and deliver, but is also influences by other external dynamics. The curriculum does not develop independently from the 'Business School' system, or from 'Business', 'Environment' and 'Society'. The further important insight, therefore relates to connectedness, which entails the engagement of a wide variety of stakeholders. Furthermore, systemic change depends on capacity-building within a business school, the provision of staff resources, staff development, remuneration to name just a few. Finally, the matrix does not allow us to develop a broader systemic account of sustainability philosophies within the curriculum. These insights regarding the integration of a systemic understanding of sustainability philosophies into the curriculum are very important and are broadly discussed by 
Molthan-Hill (2014a). However, the main research gap that emerges here is how to go beyond the curriculum to integrate sustainability from an institutional perspective. In what follows, we hope to illustrate how one would meaningfully integrate these systemic perspectives into a model that would account for systemic institutional engagement.

\section{Systemic leadership}

Distributing leadership within such a system is especially important in order to empower change agents across the entire institution (Painter-Morland, 2008). What this implies is best described in the systemic leadership literature. For example, Collier and Esteban (2000, p. 208) define systemic leadership as: "The systemic capability, distributed and nurtured throughout the organisation, of finding organisational direction and generating continual renewal by harnessing creativity and innovation." Uhl-Bien et al (2007) define systemic leadership as an emergent, interactive dynamic, which creates a complex interplay from which the impetus for change is stimulated through the interactions of heterogeneous agents. Uhl-Bien et al (2007, p. 311) distinguish between administrative leadership, adaptive leadership, and enabling leadership. Administrative leadership refers to the managerial roles and actions of individuals who occupy positions of authority in planning and coordinating organisational activities. In the case of our study, this would refer to Deans and Directors within business schools. However, a more distributed leadership function is also required for systemic integration of sustainability, i.e. what Uhl-Bien et al (2007) call "enabling leadership". Enabling leadership occurs through the actions and influence of champions, which allows for the emergence of adaptive leadership. Adaptive leadership can be described as a dynamic that emerges 
from the interactions of interdependent agents. It can be described as a "collaborative change movement" that allows adaptive outcomes to emerge in a nonlinear fashion as a result of dynamic interactions.

An understanding of the systemic dynamics that would allow institutional change to emerge, could help us define an added dimension that could be overlaid on Godemann et al's (2011) matrix. Adapting the above definitions for our purpose, we define systemic institutional integration as: "building a systemic capability towards sustainability, distributed and nurtured throughout the organisation, which creates the impetus towards change in students, faculty, administrators, the institution as a whole, as well as organisations that hire its alumni". What this entails in practice is alluded to in the literature but not fully systematised.

\section{Connectedness}

Realising the goals of sustainability education actually depends on the capacity of business schools to be connected to their constituents, to have a systemic orientation in how they approach the agenda, and to build the necessary capacity. Concerns about the increasing irrelevance of business schools are widely expressed (Augier and March, 2007; Starkey and Tempest, 2009). For instance, Schoemaker (2008) argues that business school education "has come to focus more on well-defined problems rather than the messy ambiguities of the real world". As a result, it suffers from an over-utilisation of analytical techniques, an over-reliance on static economic models and a focus on stylised markets rather than on social networks. This has led many to question the relevance of business schools for offering students insight into the complex social and human factors 
involved in business decisions (Buchholz and Rosenthal, 2008). We therefore suggest that business schools aim to better understand their core constituents and what their demands and needs are. If they were in closer contact with their constituencies they could reflect on existing capacities and offerings and devise a new strategy for embedding ESGE issues further.

Simon et al (2013) highlight that the integration of sustainability in a University context has to address systemic issues in order to overcome communication barriers and integrate highly specialised knowledge. Aalborg University offers an example of good practice in this respect, with students undertaking around ten projects during their degree to find solutions for real-life sustainability problems. This approach was critically reflected upon by Leroy et al (2001) and partially transferred to Nijmegen University in the Netherlands, since it combines the business and corporate agenda, thus demonstrating the effective transference of good practice across international borders. It also demonstrates one possibility on how the corporate agenda can feature in the business school.

\section{Capacity building}

Identifying a gap between the status quo and the anticipated best response to the core constituents could lead to changes in the curriculum and the capacities. For this process to yield systemic change, the sustainability agenda must move beyond individuals towards broad institutional buy-in and integration, which yields its own change dynamic. One would assume that as with any other institutional change process, capacity-building would entail paying attention to policy, processes and participants. In 
the business school context, this would necessitate a number of important changes. Policy-change requires more than just signing up to, for example, the Principles for Responsible Management Education (PRME) initiative from the United Nations Global Compact, and implementing a sustainability policy. In fact, Burchell et al. (2015, p. 481) argue that the soft governance processes of the PRME cannot produce the change and development that it is aimed, if agents within institutions are not empowered to effect change. Soft governance also lies at the heart if other developments in higher education reform, which include the role of accreditation bodies, league tables, student surveys and benchmarking activities (Burchell et al, 2015, p. 483). As such, these initiatives should support each other to engender change, yet the critics of soft governance argue that it tends to support the status quo instead.

Other institutional policies that often play a more important role in supporting change agents in business schools include: hiring criteria, publication strategies, and performance management policies, especially in the tenure and promotion area (Hommel, et al, 2012, p. 33). Processes would include training and development, mentoring, timemanagement/ workload planning, interdisciplinary cooperation, etc. Engaging the participants that are required for systemic includes involving developing the insights of managers and faculty across disciplinary boundaries and organisational hierarchies (Akrivou and Bradbury-Huang, 2011). This is however where most institutions seems to falter. Instead of seeking relevance and aiming towards interdisciplinary work, business schools are driven by 'science-envy' and objective measure such as rankings and accreditations (Painter-Morland, 2015). Though there is stated commitment to systemic change towards sustainability, individuals who are committed to this transformation or 
tasked with its management often don't experience real institutional support in terms of capacity building. As Akrivou and Bradbury-Huang (2011, p. 223) argue, to bring about change business schools themselves have to be transformative social context. We cannot teach our students to do what we ourselves cannot muster within our own institutions. For instance, if we treat our colleagues, subordinates and the environment as means to an end, it is difficult to convince students to respect and treat others as ends in themselves. Akrivou and Bradbury-Huang (2011, p. 230) argue that the 'habitus' of executives and boards in business schools must be addressed, and that faculty have to be integrated catalysts themselves, and not treated as commodities.

In the light of these insights the model we wish to put forward (Figure 2), proposes that the Rusinko/Godemann et al (2011) model should be supplemented with a concern for systemic institutional integration (SII). It suggests that any programme that attempts to embed sustainability, cannot succeed without: 1) systemic thinking and systemic leadership 2) connectedness to business, the natural environment and society; and 3) institutional capacity building.

\section{Insert Table 5 here: Requirements for Systemic Institutional Integration}

Insert Figure 2 here: Systemic Institutional Integration of ESGE issues into business schools

\section{Methodology and context:}

To address the research questions of this study from different stakeholders' 
perspectives within the global business schools, the results of a core exploratory survey by a third party [**removed for blind review] was employed. Two separate surveys, one for deans, and one for faculty, were initially designed by [**removed for blind review] to investigate the state of integration of ESGE issues into management education globally, from these two different perspectives. A group of experts, which included faculty teaching sustainability, as well as NGO and corporate representatives from within the network, were involved in discussions around the questionnaire construction.

Using Qualtrics.com as the survey engine, the questionnaires were circulated in 2012-13 by distributing a link to the questions by email to 1460 deans and faculty members of the global business schools who were members of $\left[{ }^{* *}\right.$ removed for blind review]. Although the response rate was just above $20 \%$, categorising the respondents to their regions, the results of 57 European deans and 67 European faculty members were selected for this research. A copy of the original questionnaire is available upon request from the authors. To satisfy confidentiality concerns, both deans' and faculty surveys were anonymous. Consequently, it prevents the deans' and faculty members' results from being fully and correspondingly linkable; and therefore these two result sets do not necessarily represent deans and faculty members from the same organisations. However, these two data sets can still be comparable as standalone results of the deans and faculty members' perspectives on the sustainability issues and integrations in the business schools across the world, regardless of their institutions and cross-sample comparisons.

These questionnaires were originally designed to gauge a broad range of questions, many of which lie beyond the scope and interest of this paper. Instead of discussing all the findings, we decided to focus on those questions that help us 1) study 
how schools are embedding sustainability in the curriculum, based on the Godemann et al framework 2) study how schools are performing in terms of our fifth practice, systemic institutional integration, based on the criteria of sustainability leadership, connectedness and capacity building. These three categories where identified based on the salient features emerging from our literature review. Using principal axis factoring as the extraction method and oblique rotation, as well as investigating the Eigen values of the factors $(>1)$, the screen plot (confirming three factors), and checking the pattern analysis for cross-loadings higher than 0.3 , three groups of items for the deans' survey were identified as:

1. Sustainability leadership (Cronbach alpha 0.839);

2. Corporate connection (Cronbach alpha 0.833 );

3. Institutional capacity building (Cronbach alpha 0.683 ).

A slightly different result was found for the EU faculty members' responses. The results initially also indicated three factors but two items had cross-loadings higher than 3 on other factors. After removing cross-loading items, two factors remained valid: 1 . Sustainability leadership and corporate connection (Cronbach alpha 0.883); and 2. Institutional capacity building (Cronbach alpha $0.602^{2}$ ). In the remainder we view sustainability leadership and corporate connection as one item ('connected leadership') since sustainability leadership and corporate connection came out as 1 factor in the Faculty member survey.

None of the other Cronbach's alphas were less than 0.972 if any item was deleted, which

\footnotetext{
2 This value could be improved to 0.609 when removing cross-loading item.
} 
is well above the lower limit of 0.7 (Hair et al., 2006).

In reflecting on our data, we would like to assess where most schools from the sample are in terms of the various dimensions/practices, in order to assess the most common approaches to embedding sustainability. Secondly, we will be exploring whether schools are engaging in systemic institutional integration (SII) by using our suggested framework to make sense of the data collected and to teach us valuable lessons in assessing the status quo in a business school, as well as indicating a way forward.

\section{Justification of Core Questions selected from questionnaire:}

We decided to group the questions for 'Piggybacking' and 'Mainstreaming' together in the discussion of the descriptive data emerging from the data, as they are two opposites of a continuum. Descriptive data emerged from questions that asked of Deans and faculty to indicate the number of courses they offer with ESGE-related content. Depending on the extent to which schools integrated ESGE content into existing modules, we characterized their practice as either 'Piggybacking' or 'Mainstreaming'. We differentiated between 'Mainstreaming' and 'Piggybacking' in the following way: If in average postgraduate programmes offering five or more modules with integrated ESGE-related content, we classified it as 'Mainstreaming', as it would mean that ESGE issues are discussed in half or more of the programme content. However if the average postgraduate programmes offer two to four modules with ESGE-related content, we would question whether this can still be classified as 'Mainstreaming', and if it included only one module with ESGErelated content, we suggest that this is clearly 'Piggybacking'. 
Respondents to the survey were asked a number of perception-based questions that helped us gauge the level of 'Mainstreaming' of the sustainability agenda within business schools. For instance, they were asked to what extent do they agreed with the following statement: "In the past ten years, ESGE issues in business schools and universities have moved from the fringe to the mainstream in management research and education" $(\mathrm{Q} 4.5)$ Since this question directly tested respondents' agreement regarding the existence of 'Mainstreaming' in business schools, it was selected as an additional core component in the 'Mainstreaming' quadrant. To revalidate this result, we also used the perception of both groups regarding whether their institutions have been successful in embarking on a change management to integrate ESGE-related issues into the teaching practice (question 2.6 of the questionnaire).

In the case of the two quadrants of the Godemann et al (2011) framework that pertain to new structures, we have grouped 'Digging deep' and 'Focusing' together as they are also on a continuum. To judge whether schools are 'Digging deep', we looked into deans' and faculty members' reporting on the existence of elective modules, and core modules on ESGE-related issues. We are basing our analysis on the assumption that business schools that offer predominantly electives could be classified as 'Digging deep'. These business schools might not offer so many modules on ESGE issues in their core programmes, but they have enough electives on offer so that a student can decide to become an expert in this area

The 'Focusing' approach requires of schools to develop new interdisciplinary offerings or new programme (degrees, or majors and minors in degree) in the area of sustainability. Compulsory modules are therefore an indication of 'Focusing', but only if they reach a 
certain proportional weight within the curriculum. Deans and faculty were asked about the number of compulsory modules on ESGE-related issues (Q. 2.7). We therefore looked at whether there were significant numbers of new core modules within the schools' various programmes. The questionnaire also contained a very helpful question testing respondents' agreement that their institutions encourage collaboration between faculty for interdisciplinary courses on sustainability issue. We included data emerging from this question as supplemental information within our analysis.

On the 'connected leadership' dimension, we identified two core questions each for both 'leadership' and for 'connectedness' from the survey. On the 'leadership' dimension, the first one asked respondents to indicate their agreement with the statement that "the ESGE agenda is fully integrated into their institution's mission, values and sense of purpose" (Q. 2.1.). Secondly, to gauge leaders' commitment to systemically embedding this commitment across the institution, we looked at agreement with the statement: "To what extent do you agree with the following statement: "The Dean / Director of my institution supports a number of champions who lead the ESGE agenda at various levels of the institution.” (Q. 2.4).

In terms of connectedness, we used two questions from the survey, asking respondents to what extent do they agree that: "Business schools and universities are close enough to the corporate ESGE agenda to formulate an appropriate response" (Q. 1.3) and that their institution is: "close enough to the corporate ESGE agenda to formulate an appropriate response" (Q. 1.4). We also looked at questions indicating whether schools are proactive in reaching out to their corporate audiences (Q. 3.1.) and whether corporate messages 
regarding sustainability priorities are being clearly communicated to schools and Universities (Q. 3.2.).

To investigate the kind of capacity that is being built towards systemic institutional integration of sustainability, we identified 3 core questions. The first one looks into whether schools have embarked on change management processes processes to embed ESGE within our core teaching and research programmes (Q. 2.6), and considered whether resistance to change was experienced. We also considered capacity building initiatives such as training (Q. 4.8) and HR integration (Q. 4.9) as core components in capacity building.

\section{Empirical analysis and key findings:}

We start the analysis by looking for evidence in the survey that business schools are utilizing one or more of the four approaches outlined by Godemann et al (2011). Secondly, we will adopt the framework of Godemann et al by adding a fifth dimension, which we call "Systemic institutional integration" (SII) - exploring the two criteria for SII, i.e. connected leadership and capacity building.

\section{Part 1: Current curriculum practices}

\section{'Piggybacking'vs. 'Mainstreaming'}

As explained above, 'Piggybacking' occurs when schools integrate sustainability components into some of their existing modules; and 'Mainstreaming' only takes place if schools integrate sustainability-related issues into the majority of their modules across the 
board. To study how European deans and faculties evaluate their 'Mainstreaming' practice, both EU deans and faculty members were asked if they believed that ESGE issues in business schools and universities have moved from the fringe to the mainstream in management research and education (Q. 1.2). Although both groups did not largely agree that they have successfully moved to 'Mainstreaming', deans proved to be slightly more optimistic with a significant difference $(p=0.009)$ between the means (deans: a mean of 3.55 on a scale from 1-5 vs. faculty members: 3.22 ).

To revalidate this result, both groups were asked if they believe their institutions have been successful to embark on a change management to integrate ESGE-related issues into the teaching practice (Q. 2.6 of the questionnaire). Although none of the groups had a high level of agreement with the statement, we found that EU deans scored significantly higher than EU faculties (mean 3.91 vs 3.24; $\mathrm{p}=0.0005$ ). This implies that on average deans are stronger believers than faculty members that their institutions had been successful to integrate sustainability-related issues into the teaching practices. However, when looking at the actual modules available, it seems few schools have progressed from 'Piggybacking' to 'Mainstreaming'. We compared deans' opinions on how many modules offered by their institution have ESGE-related content integrated across the curriculum, with those of faculty members (Q. 2.7.7). Using a t-test, no significant difference was seen between deans' and faculty members' responses $(p=0.97)$. The total average of the number of such modules reported by both groups was 3.2 modules. This means that though some integration of ESGE issues into other modules in the curriculum is taking place, it is by no means mainstreamed into the majority of modules on offer. 
Since the majority of the schools seem to be Piggybacking, we looked at the data to identify the disciplines within which the integration of ESGE-issues is taking place. Nine different disciplines where identified and studied, comprising accounting, economics, finance, entrepreneurship \& innovation, HRM \& organisational behaviour, leadership, marketing, operations \& supply chain management and strategy. We conducted a principal components analysis with varimax rotation and extracted 2 different factors. The first factor consists of the first three disciplines, which we call AEF (accounting, economics, finance) disciplines. The second factor consists of the other items, which we refer to as the management disciplines. The sample adequacy of KaiserMeyer-Olkin (KMO) was 0.826, well above the acceptable limit of 0.5 (Field, 2009). Using a t-test we found that AEF disciplines scored significantly lower on the sustainability integrations ratio than management disciplines (an average score of 6 out of 10 for management disciplines as opposed to 4.1 out of 10 for FEA disciplines, $\mathrm{p}<0.01$ ). This means that European faculty members believe sustainability-related issues are more integrated in management disciplines (in particular in Strategy and Leadership) than in others. This is in line with Starik et. al (2010) who highlighted that most business Schools find it easier to integrate sustainability into strategic management, ethics and public policy. However the lower integration of sustainability into accounting and marketing, as believed by faculty members, comes as a surprise, since both subject areas have developed a good body of knowledge in the last decade, with the publication of numerous articles and several books on these subjects on which modules, lectures and seminars can be based (see for example, Schaltegger et al, 2006; Belz and Peattie, 2009; Hopwood et al, 2010; Dahlstrom, 2011; Osbourne and Ball, 2011; Martin and Schouten, 2012; Unermann 
et al, 2014).

Generally, we find that schools have started to integrate ESGE issues in particular in management discipline subjects, but there is scope for further development. This supports the idea that on average European business schools are currently 'Piggybacking' in most subject areas. We did not find significant evidence of broad 'Mainstreaming' across disciplines. This is also reflected in the limited literature on offer; only recently specialised textbooks have been developed that integrate ESGE issues throughout each subject area (Molthan-Hill, 2014b; Weybrecht, 2014).

\section{'Digging deep'Vs. 'Focusing'}

As discussed before, 'Digging deep' happens when business schools attempt to develop few and stand-alone new compulsory or electives modules, which are specifically designed to embed ESGE-related issues. However, if the number of these modules are large enough and their subjects' coverage are broad enough to address the broader curriculum, and to allow students to graduate with majors or minors in sustainability, then the practice may shift from 'Digging deep' to 'Focusing'.

To judge whether schools are 'Digging deep', we investigated deans' and faculty members' responses to the total number of new ESGE-related compulsory and elective modules in postgraduate programmes. The result shows no significant difference between EU deans and faculties' responses. We therefore merged both datasets for this analysis and table 1 below shows the result of the numbers of compulsory and elective ESGErelated modules on the postgraduate programmes in European business schools. 


\section{Insert Table 6 about here: ESGE-related modules in various business school programmes}

As shown in table 1, more than half of EU business schools offer no more than one compulsory ESGE-related module in their postgraduate programmes. This highlights that on average around $60 \%$ of the EU business schools are currently 'Digging deep' by introducing only one ESGE-related compulsory module to their existing postgraduate programmes. However, $30 \%$ of the EU business schools are in transition from 'Digging deep' to 'Focusing' by developing two to four new ESGE-related compulsory modules into their existing postgraduate programmes, and only $11 \%$ of the EU business schools are currently 'Focusing' with more than five compulsory ESGE-related modules. 'Focusing' would mean that in these programmes, ESGE-related content forms the largest part of the entire programme, and new interdisciplinary courses have been developed that allow students to graduate with a major or minor in sustainability, or have a MBA or other postgraduate degree in sustainable business.

The number of elective modules, however, can also be used to further explain 'Digging deep' and 'Focusing' practices with a focus on the choice made by students. We found that $51 \%$ of the EU business schools have developed between two to four new elective ESGE-related modules. This shows an attempt to shift from 'Digging deep' to 'Focusing' by offering relevant elective modules. About only one-third (32\%) have already introduced more than five ESGE-related electives. These business schools might not offer so many modules on ESGE issues in their core courses, but they have enough electives on offer so that a student can decide to become an expert in this area. These electives might often go into detail, so that the students are really 'Digging deep' with 
regard to one specific topic e.g. Greenhouse Gas Management. They may also offer additional sustainability related content to each subject area such as an elective in 'Sustainable Management', which includes tools for e.g. Accounting, Marketing, and Supply Chain. The high percentage indicates that most business schools have followed the 'Digging deep' approach; this might be due to the ease of adding a module to an existing curriculum rather than changing the entire curriculum. This might be the most obvious point to start the journey to embedding sustainability into the curriculum, however as mentioned before, in this case students can choose to finish their course at a business school without any exposure to ESGE issues at all if they choose not to take none of these electives.

\section{Insert Figure 3 about here: Transition from 'Digging deep' to 'Focusing' in average European postgraduate programmes}

To further investigate whether the 'Focusing' approach is likely to become a common practice in EU business schools, we drew on the survey question in which both deans and faculty members were asked if their institutions encourage collaboration between faculty for interdisciplinary courses on sustainability issue. A t-test shows there is no significant difference in their answers (Deans average equals 3.77, compared to 3.68 for the faculty members). This means both dean and faculty groups are modest believers that 'Focusing' must be part of their future practice in bringing new ESGE-related programmes into business school curricula.

Overall, one can argue that although individual European business schools in our survey have adopted all four approaches, 'Piggybacking' and 'Digging deep' are the 
current main practices and 'Focusing' practice is increasingly becoming an aspiration, while there seems to be agreement amongst deans and faculty members that ESGE issues are not integrated into enough modules to constitute a 'Mainstreaming' approach.

\section{Part 2: Systemic institutional integration}

We believe that the most critical success factors lie in the overall level of strategic, institutional commitment that exists towards the ethics and sustainability agenda. In line with the factors analysed we develop a set of criteria for this institutional commitment: 1) connected, systemic leadership and 2) institutional capacity-building.

\section{Connected, Systemic Leadership:}

As described above systemic leadership can be defined as an emergent, interactive dynamic, which creates a complex interplay from which the impetus for change is stimulated through the interactions of heterogeneous agents (Uhl-Bien et al, 2007). UhlBien et al's (2007, p. 311) description of different leadership roles drew our attention to the importance of distributing the responsibility for leading change towards sustainability among multiple interconnected agents within the organisation. From our data, we can investigate how deans and directors within business schools lead on the agenda, but also gauge whether these leadership roles are distributed amongst a broader group of champions. Deans and directors, who can be described as the 'administrative leaders' in our study, have stronger views on whether the ESGE agenda is fully integrated into their institution's mission (question 2.1) than our faculty respondents. A t-test shows deans are significantly stronger believers than faculty members (average score of 3.78 for deans 
and 3.1 for the faculty members, $\mathrm{p}<0.01$ ). Furthermore, when deans were asked if they consider themselves responsible for leading developments of its ESGE agenda (Q. 2.3 deans' survey), a strong majority were in favour of the statement (average $=4.27$ out of 5, $\operatorname{std}=0.73)$.

However, a more distributed leadership function is also required for systemic integration of sustainability, i.e. what Uhl-Bien et al (2007) call "enabling leadership". Enabling leadership occurs through the actions and influence of champions, which allows for the emergence of adaptive leadership. Faculty members believed significantly less that their deans and directors of their institutions support champions who lead the ESGE agenda in their institutions than the extent to which deans' believe they are supportive of champions $(\mathrm{p}<0.01)$. We furthermore asked deans and faculty members whether they believe "The Dean / Director of their institution takes responsibility for leading the development of its ESGE agenda" (Q. 2.3). The result shows a significant disagreement between deans and faculty members (deans average $=4.2$ out of 5 , std $=0.72$; faculty member average $=3.3$ out of $5, \mathrm{std}=1.14, \mathrm{p}<0.01$ ). This shows that either deans overestimate their own support, or faculty members do not fully experience the leadership support of their superiors.

Realising the goals of sustainability education depends on the capacity of business schools to be connected to their constituents. Faculty members indicated no significant agreement $(2.92$ out of $5, \mathrm{std}=0.95)$ that "business schools and universities are close enough to the corporate ESGE agenda to formulate an appropriate response" (Q. 1.3). Deans scored better (3.34 out of $5, \mathrm{std}=0.88$; average score of deans vs. faculty significantly different with $\mathrm{p}<0.01)$. The majority are not convinced or even disagree that 
the sector reacts appropriately to corporate demand, as most deans and faculty claim that business schools in general have not a good understanding of their core constituents, the corporations. However, both deans and faculties are more optimistic when they were asked if their own institution is "close enough to the corporate ESGE agenda to formulate an appropriate response" (Q. 1.4) (Deans average score $=4.04$ out of 5 , std $=0.75$; faculty member average score $=3.34$ out of $5, \mathrm{std}=1.09$; significant difference with $\mathrm{p}<0.01$ ). This shows although both deans and faculty members believe that other business schools are not close enough to the corporate agenda; they consider their own institutions above the norm in this regard.

To understand how both groups estimate their support to the businesses regarding the ESGE agenda we asked deans and faculties if they believe their institutions are "proactive in helping companies to define the sustainability issues and dilemmas that are most material to their core business" (Q. 3.1). Although both groups were generally in favour of the statement, yet deans were more optimistic (deans average score $=3.78$ out of 5 , std $=0.9$; faculty member average score $=3.15$ out of 5 , std $=1.15$; significant different with $\mathrm{p}<0.01)$. However, to study if deans and faculty members believe their external partners clearly communicate with them on their ESGE-related needs, deans and faculty members were asked if the corporate partners and clients of their institutions provide clear messages about their sustainability-related priorities for executive and management education" (Q. 3.2). The result was not very different from the last question (deans average score $=3.48$ out of $5, \mathrm{std}=0.75$; faculty member average score $=3.05$ out of 5 , std $=0.9$; significant difference with $\mathrm{p}<0.01$ ). This somewhat optimistic result regarding their own institutions' proactive engagement with companies does not seem to translate to 
perceptions regarding business schools' overall connectedness to the corporate agenda. The problem of biased self-reporting regarding respondents' own school's performance may lie at the heart of this. But even despite this optimism, respondents also did not fully agree that corporate messages are coming through clearly.

Overall, there seems to be a strong awareness amongst deans and Directors that they have to lead on the sustainability agenda and that they need to support other champions within their schools to do so as well. This clear commitment however does not seem to register fully within the perceptions of faculty members. The same problem seems to exists between schools and their corporate constituents - though there is clear agreement that the connection is important, and that most schools believe they seek this contact, the messages that should be conveyed do not seem to come through clearly.

\section{Capacity building:}

Deans and faculties were asked if their institutions have "embarked on change management processes to embed ESGE within our core teaching and research programmes" (Q. 2.6). Both groups showed reasonable agreement; deans were in significantly higher agreement than faculty members (deans average score $=3.8$ out of 5 , $\mathrm{std}=0.95$; faculty members average score $=3.2$ out of $5, \mathrm{std}=1.12 \mathrm{p}<0.01$ ).

On the positive side, it seems that actual resistance against internal change is relatively low. Deans and faculties were asked "To what extent do you agree with the following statement: I have encountered resistance to internal change around ESGE issues from", with 7 different factors of internal resistance, comprising alumni, administration, external sponsors, faculty, programme directors, students and 
trustees/governors (Q. 2.10). To analyse the results, first an exploratory factor analysis were considered to see what the main resistance factors are. Exploratory factory analysis with varimax rotation extracted only one Resistance factor. Using a t-test we found that deans scored significantly lower on the factor resistance than faculty members (deans average score $=2.56$, faculty members average $s c o r e=2.92$; significant difference with $\mathrm{p}<0.01)$. This means both EU deans and faculty members have experienced reasonably low internal resistance to change around ESGE issues, although not surprisingly deans reported lower average internal resistance to change.

Unfortunately, though there may not be resistance to change, there also seem to be little active support. When asked if their institutions "offer training to build sustainabilityrelated skills and competences..." (Q. 4.8 of faculty members survey) it was found that faculty members on average do not highly support this statement (average faculty member score $=2.8, \mathrm{std}=1.43$ ). When comparing the perceptions of deans and faculties on whether their institutions offer training to build sustainability-related skills and competencies to their staff, the result was significantly different (see Table 2 below).

\section{Insert Table 7: Training in sustainability-related skills and competences}

As the faculty should know about these possibilities as the recipients of this training, one wonders whether there is again a mismatch between the perception of the deans and what is actually happening. And it also raises the question, whether staff would need more training to be able to mainstream ESGE issues into their teaching. Maybe in some cases deans believe that faculty can integrate ESGE issues into to their subject areas without further training?

On the positive side, responses show promising views on campus management 
from the deans survey, including facilities, reducing environment footprint, having sustainability related criteria in procurement process, policy-designs, as well as engagement with local communities (Q. 4.9 of the deans survey). Using exploratory factor analysis we found one component for the deans' opinion on full integration of sustainability considerations into campus management; the average score on this factor was $3.8(\mathrm{std}=0.85)$.

Unfortunately the commitment towards integration of sustainability into campus management procedures is not matched with similar resolve in integrating it into human resource management. Deans and faculty members were asked "To what extent do you agree with the following statement: "My institution integrates sustainability-related criteria into its HR policies" with 4 factors of Recruitment \& Retention, Annual Performance Evaluations, Tenure \& Promotion Processes and Selection for Senior Management Roles (Q. 4.9 of the faculty members survey). Again, we explored factors using exploratory factor analysis and found only one factor for the faculty member opinion on how their institutions integrate sustainability-related criteria into the HR policies, with an average score of $2.7(\mathrm{std}=0.85)$. This shows faculty members generally do not really believe that their institutions' HR policies integrate ESGE-related criteria.

According to the analysis above, faculty members do not have an incentive to integrate ESGE issues into their work (besides maybe a moral conviction that they want to do it) as it does not support their career in any of the HR criteria mentioned above nor by achieving a good research output. This could create capacity problems, as faculty members do not seem to have the institutional support to prioritize the sustainability agenda in their overall career planning. It is very important that commitment to this 
agenda be reflected in hiring criteria, performance management and promotion.

\section{Conclusion}

In this paper, we make two, interrelated contributions. Firstly, we display the range of initiatives that schools are taking to embed sustainability within the curriculum. We believe, however that existing curriculum initiatives could be improved by considering the systemic nature of sustainability. The framework as developed by Godemann et al (2011) focused on how ESGE issues should be taught but did not consider the broader systemic integration within business schools, which could drive change.

Though there are signs that ESGE issues have become a more mainstream concern within business schools and Universities, perceptions about the success of the integration differ. There are many positive signs, for example the fact that more courses are integrated into curriculum and sustainability is embedded into campus management models. We have shown in the analysis that all four approaches outlined by Godemann et al (2011) are pursued by business schools, which indicates that most of the respondents are already trying to embed ESGE issues into the curriculum. Some are 'Focusing' by developing interesting new interdisciplinary offerings, which is a prominent approach emerging from the literature (Stubbs and Schapper, 2011; Du et al, 2013; Chhokar, 2010). However, the majority are 'Piggybacking' by integrating some cases or ESGE content into an existing module. This is the starting point for most lecturers, since it is easier to achieve than redesigning a whole module.

Based on our analysis, we would argue that though business schools can adopt the 
different approaches, both 'Mainstreaming' and/or 'Focusing' have distinct advantages (Birtch and Chiang, 2014). In the case of 'Mainstreaming', all students within the business school will be exposed to sustainability-related issues in most of their courses as part of their general education. In the case of 'Focusing', some students' entire degree programme will be able to shaped by newly created interdisciplinary modules or programmes that allow them to be experts in sustainable management. Both 'Mainstreaming' and 'Focusing' allow students to reflect on their own values and experiences and link them to the subjects taught. We believe that instead of working on case studies, students could be given real-life problems from the core constituents of a business school and work in partnership with them on solving these challenges, not by reducing them to simplistic problems but by learning how to deal with ESGE issues in all their ambiguity.

Our second contribution relates to the development of a fifth practice/dimension in integrating sustainability into the business schools. In this dimension, the focus is on moving beyond the curriculum towards developing systemic support for sustainability across the business school and through all its operations. We argue that integrating sustainability into the curriculum must be closely aligned with systemic institutional integration. This requires connectedness, systemic leadership, and the development of the capacities of all staff members. Our analysis of the survey data has supported the need for such a fifth practice. We have highlighted that a strong leadership is crucial for embedding sustainability across the whole institution. Though Deans clearly view this as part of their leadership task, the discrepancy between deans' perceptions and those of faculty on whether this is experienced in practice, is striking. While deans would see 
themselves as strong leaders on this agenda, faculty would question this.

Internally, our findings indicate that there are insufficient incentives for faculty to integrate sustainability into their research and teaching activities. As a result, people may easily lose motivation to drive activities further. Faculty will also react to the ethical climate provided to them; when certain ESGE topics are not rewarded within HR policies around hiring, annual performance reviews and promotion, this might have an adverse effect on staff. These situational-individual interactions, which Birtch and Chiang (2014) analysed with regard to the ethical behaviour of students but not with regard to faculty, need further investigation but it is quite likely that staff members are also highly influenced by the institutional appreciation of ESGE issues in teaching, research and HR policies.

Our framework suggests further to follow the systemic approach toward embedding ESGE issues in business schools' corporate strategy to set their internal policies, assign the right capacity and communicate with their core constituents. It indicates that if any of the links become missing or broken, then business schools may find it difficult to fully build the necessary capacity for sustainability-related internal curriculum approaches ('Piggybacking', 'Mainstreaming', etc.). It is also interesting that in our study most deans criticised the sector for not being close enough to the corporate agenda, whilst considering themselves and their own institution to be at the forefront of this development.

At the same time, supporting the appropriate level of knowledge-creation through ESGE-related research, as well as maintaining the appropriate level of mutual communication with their core constituents, remain challenging. The schools would need 
to both create and allocate the level of capacity needed to embed ESGE issues in their context, depending on what sustainability-related policy they follow. They also need to make most of the capacities which may be available from their core constituents (guest lecturing, research capacities, funds, etc.). The role of these core constituents is highly important to the way the entire process works, as in healthy and dynamic collaboration they act as suppliers (of funds, research agendas, etc.), contributors to internal operations (with teaching material, case-studies, guest lecturing, etc.) and also as customers of the created knowledge and the output policies/operations. By best utilising these capacities, schools can align their approach to the curriculum, to our fifth dimension in order to ensure systemic institutional integration.

To move the sustainability agenda further towards effecting real change, a number of further key challenges remain. The differences between leadership perception and that of faculty who are involved in the daily practice of facilitating the integration of sustainability-related issues within their schools, warrant further research. Changes such as the introduction of innovative curricula and alternative delivery modes (Muff et al, 2013) would need to be embraced by deans in order to take the sustainability agenda forward in Universities. Agreement between deans and faculty members around key drivers for change, and a shared understanding of resistance to the agenda from all stakeholders concerned, will consequently be important going forward.

\section{Limitations}

Our research is limited by the fact that we only analysed responses from European deans and faculty members. Since the data we had access to did not reveal the country of 
origin of the European respondents, we could not perform a more stratified regional analysis. The data available only allowed us to distinguish between European and NonEuropean Deans, and European faculty. Though we had some responses from non-EU Deans, we decided to filter this data out of our analysis, as the non-EU data was not large and rigorous enough for a valid statistical analysis ${ }^{3}$. In addition, though it was anticipated at the outset of the study that differences in perceptions from EU and non-EU deans would be revealed, views between deans within and outside EU countries were mostly similar. This may be the case because senior management members from European origin, or being educated within, or having significant experience in European settings, are often appointed within non-European schools. Our data however did not allow us to validate this hypothesis. Future research can be universal and more specific about the regions and explicitly incorporate perspectives from other regions with a large concentration of business schools, including the US but also regions in Asia.

A further limitation relates to the fact that deans and faculty who selected to fill out the questionnaire are clearly already committed to the ESGE-agenda, and as such, may believe their schools to be leaders in this area. This may have skewed some of the perception data, though we believed that statistical analysis allowed us to report rigorous data.

3
\begin{tabular}{|l|l|l|l|}
\hline No & Region & $\begin{array}{l}\text { Number of Respondents } \\
\text { (Dean's Survey) }\end{array}$ & $\begin{array}{l}\text { Number of Respondents } \\
\text { (Faculties' Survey) }\end{array}$ \\
\hline 1 & $\begin{array}{l}\text { Africa excluding Middle East and North } \\
\text { Africa }\end{array}$ & 3 & 6 \\
\hline 2 & Asia & 14 & 5 \\
\hline 3 & Australasia and New Zealand & 6 & 3 \\
\hline 4 & Latin America \& Caribbean & 6 & 1 \\
\hline 5 & Middle East and North Africa & 7 & 1 \\
\hline 6 & North America and Canada & 9 & 5 \\
\hline 7 & South America & 5 & 2 \\
\hline 8 & Europe & 57 & 67 \\
\hline
\end{tabular}


Furthermore, our research does not provide the opportunity to establish a ranking of practices that contribute to the success of a business school in embedding sustainability in the curriculum. As such, an interesting area that we have not been able to address is the success vs failure of initiatives. Particularly investigating initiatives that have not been successful may provide useful information for improving the embedding of sustainability in educational programmes. Longitudinal case studies on the development of sustainability-focused education programmes are necessary to be able to establish this.

For future studies, some focus-group analysis and semi-structured interviews with deans and faculty members may narrow down the results of our study to further clarify the implementation of different practices that were introduced by this research.

\section{Bibliography}

Akrivou, K., \& Bradbury-Huang, H. (2015). Educating integrated catalysts:

Transforming business schools toward ethics and sustainability. Academy of Management Learning \& Education 14 (2), 222-240.

Augier, M. and March, J.G. (2007). The Pursuit of Relevance in Management Education. California Management Review 49 (3), 129-146.

Baden, D. (2013). Chapter 6, No more preaching to the converted: Embedding ESD in the business school curriculum through a service learning initiative. In R. Atfield and P. Kemp (eds.), Enhancing education for sustainable development in Business and 
Management, Hospitality, Leisure, Marketing, Tourism. York, UK, Higher Education Academy. Available online at:

https://www.heacademy.ac.uk/sites/default/files/ESD_Baden_final_0.pdf

Baets, W. and Oldenboom, E. (2009). Rethinking Growth: Social Intrapreneurship for Sustainable Performance. Palgrave Macmillan.

Belz, F.M. and Peattie, K. (2009). Sustainability Marketing: A Global Perspective. Chichester, Wiley.

Birtch, T.A. and Chiang, F.F. (2014). The Influence of Business School's Ethical Climate on Students' Unethical Behavior. Journal of Business Ethics 123, 283-294.

Buchholz, R.A. and Rosenthal, S.B. (2007). The unholy alliance of business and science. Journal of Business Ethics 78, 199-206.

Burchell, J., Kennedy, S., \& Murray, A. (2015). Responsible management education in UK business schools: Critically examining the role of the United Nations Principles for Responsible Management Education as a driver for change. Management Learning 46(4), 479-497.

Chhokar, K.B. (2010). Higher education and curriculum innovation for sustainable development in India. International Journal of Sustainability in Higher Education 11 (2), 141-152.

Clayton, A.M.H. and Radcliffe, N.J. (1996). Sustainability: A systems approach, London, Earthscan.

Collier, J. and Esteban, R. (2000). Systemic leadership: Ethical and effective. Leadership \& Organization Development Journal 21(4), 207 - 215.

Courtice, P. and van der Kamp M. (2013). Developing leaders for the future: Integrating 
sustainability into mainstream leadership programmes. Working paper of the Cambridge Programme for Sustainability Leadership, commissioned by the Academy of Business in Society.

Currie, G., Knights, D. and Starkey, K. (2010). Introduction: A post-crisis critical reflection on business schools. British Journal of Management 21, S1-S5.

Dahlstrom, R. (2011). Green Marketing Management. Andover, South-Western Cengage. De Dea Roglio, K. and Light, G. (2009). Executive MBA programs, the development of the reflective executive. Academy of Management Learning and Education 8(2), 156173.

Du, X.Y., Su, L. and Liu, J. (2013). Developing sustainability curriculum by using the PBL method in a Chinese context. Journal of Cleaner Production 61, 80-88.

Field Andy (2009). Discovering statistics using SPSS. Sage publications.

Godemann, J., Herzig, C. and Moon, J. (2011). Approaches to changing the curriculum. Presentation given on the ISIBS Workshop - Session II, University of Nottingham 20/21.10.2011.

Goworek, H. and Molthan-Hill, P. (2013). Embedding CSR within the undergraduate business curriculum: The development of a Sustainable Organisation module. In J. Ahmad, J. and D. Crowther (eds.), Education and Corporate Social Responsibility: International perspectives. Bingley: Emerald Publishing, 57-76.

Hair, J. F., Black, W. C., Babin, B. J., Anderson, R. E., \& Tatham, R. L. (2006). Multivariate data analysis (Vol. 6). Pearson Prentice Hall, Upper Saddle River, NJ. Hartman, L.P. and Werhane, P.H. (2009). A modular approach to business ethics integration: At the intersection of the Stand-Alone and the Integrated approaches. Journal 
of Business Ethics 90, 295-300.

Holt, D. (2003). The role and impact of the business school curriculum in shaping environmental education at Middlesex University. International Journal of Sustainability in Higher Education 4(4), 324-343.

Hommel, U., Painter-Morland, M. and Wang, J. (2012). Gradualism prevails and perception outbids substance. Global Focus, 6(20), 30-33.

Hopwood, A., Unerman, J. and Fries, J. (eds.) (2010). Accounting for Sustainability: Practical Insights. London, Routledge.

Hühn, M.P. (2013). You reap what you sow: How MBA programs undermine ethics. Journal of Business Ethics 121, 527-541.

Kiron, D., Kruschwitz, N., Haanaes, K., \& von Streng Velken, I. (2012). Sustainability nears a tipping point. MIT Sloan Management Review 53(2), 68-75.

Kurland, N.B., Michaud, K.E.H., Best, M., Wohldmann, E., Cox, H., Pontikis, K. and Vasishth, A. (2010). Overcoming silos: The role of an interdisciplinary course in shaping a sustainability network management education, Academy of Management Learning and Education 9(3), 377-383.

Lämsä, A.M., Vehkaperä, M., Puttonen, T. and Pesonen, H.L. (2008). Effect of business education on women and men students' attitudes on Corporate Responsibility in society. Journal of Business Ethics, 82, 45-58.

Leroy, P., van den Bosch, H. and Ligthart, S. (2001). The role of project-based learning in the "Political and Social Sciences of the Environment" curriculum at Nijmegen University. International Journal of Sustainability in Higher Education 2(1), 8-20. Martin, D. and Schouten, J. (2012). Sustainable Marketing. Upper Saddle River, NJ, 
Prentice Hall.

Molthan-Hill, P. (2014a). A new framework for embedding sustainability into the business school curriculum. In: P. Molthan-Hill, (ed.), The Business Student's Guide to Sustainable Management: Principles and Practice. Sheffield: Greenleaf Publishing, 2014, ch. 2, pp. 7-25.

Molthan-Hill, P. (ed.) (2014b). The Business Student's Guide to Sustainable Management: Principles and Practice. Sheffield, Greenleaf Publishing. Muff, K., Dyllick, T., Drewell, M., North, J., Shrivastava, P. and Haertle, J. (2013). Management Education for the World: A Vision for Business Schools Serving People and Planet. Northampton, MA: Edward Elgar Publishing.

Osbourne, S. and Ball, A. (eds.). (2011). Social Accounting and Public Management: Accountability for the Common Good. Abingdon, Routledge.

Painter-Morland, M.J. (2008). Systemic Leadership and the Emergence of Ethical Responsiveness, Journal of Business Ethics, 82(2), 509-524.

Painter-Morland, M.J. (2015). Philosophical assumptions undermining responsible management education. Journal of Management Development 34(1), 61-75.

Rasche, A. Gilbert, D. U. and Schedel, I. (2013). Cross-disciplinary ethics education in MBA programs, rhetoric or reality? Academy of Management Learning and Education $12(1), 71-85$.

Roome, N. (2005). Teaching sustainability in a global MBA: Insights from the One MBA. Business Strategy and the Environment. 14, 160-171.

Rusinko, C.A. (2010). Integrating sustainability in management and business education. The Academy of Management Learning and Education 9(3), 507-519. 
Schaltegger, S., Bennett, M. and Burritt, R. (eds.) (2006). Sustainability Accounting and Reporting. Dordrecht, Springer.

Schoemaker, P.J.H. (2008). The future challenges of business: Rethinking management education. California Management Review 50(1), 119-139.

Simon, D. and Lundebye, A. (2013). Stepping outside a comfort zone: transdisciplinary innovation in sustainability education. In Atfield and Kemp (eds.) Enhancing education for sustainable development in business and management, Hospitality, Leisure, Marketing, Tourism. HEA: York

Starik, R., Marcus and Clark (2010). Editorial: In search of sustainability in Management Education. Academy of Management Learning \& Education , 9(3), 377-383.

Starkey, K. and Tempest, S. (2009). The Winter of Our Discontent: The Design Challenge for Business Schools. Academy of Management Learning and Education 8 (4), 576-586. Sterling, S. (2004). Higher education, sustainability and the role of systemic learning. In P. Corcoran and A. Wals (eds.), Higher Education and the Challenge of Sustainability: Contestation, critique, practice, and promise. Dordrecht, Kluwer Academic.

Stibbe, A. (2009). The Handbook of Sustainability Literacy: Skills for a changing world. Totnes, Green Books.

Stubbs, W. and Schapper, J. (2011). Two approaches to curriculum development for educating for sustainability and CSR. International Journal of Sustainability in Higher Education 12(3), 259-268.

Ten Bos, R. and Bevan, D. (2011). Sustainability. In: Painter-Morland, M.J. and Ten Bos, R. (eds) Business Ethics and Continental Philosophy. Cambridge: Cambridge University Press. 
Truscheit, A. and Otte, C. (2007). Sustainable games people play: Teaching sustainability skills with the aid of the role-play, NordWestPower. In Galea, C. (ed.) Teaching Business Sustainability. Volume 2: Cases, Simulations and Experiential Approaches. Sheffield, Greenleaf, 164-170.

Uhl-Bien, M., Marion, R. and McKelvey, B. (2007). Complexity Leadership Theory: Shifting leadership from the industrial age to the knowledge era. The Leadership Quarterly 18 (4) 298-318.

Unerman, J., Bebbington, J. and O’Dwyer, B. (eds.) (2014). Sustainability Accounting and Accountability, $2^{\text {nd }}$ edition. London, Routledge.

WCED (1987). Report of the World Commission on Environment and Development: Our Common Future. United Nations World Commission on Environment and Development, Oxford University Press.

Werhane, P. W. and Painter-Morland, M. (eds) (2011). Leadership, Gender and Organization. Dordrecht, Springer.

Weybrecht, G. (2013). The Sustainable MBA: A Business Guide to Sustainability. Chichester, John Wiley and Sons.

Table 1: Insert Table 1 here: Examples, challenges and opportunities of "Piggybacking".

\begin{tabular}{|l|l|l|}
\hline Piggyback example & Challenges and opportunities & Source \\
\hline Inclusion of visiting lectures by & Can reach many students but may be & Lämsä et al (2008) \\
leading business people about & viewed as 'supplementary' & \\
\hline
\end{tabular}




\begin{tabular}{|c|c|c|}
\hline CSR & $\begin{array}{l}\text { Sustainability reaches students in a } \\
\text { non-uniform manner }\end{array}$ & Rusinko (2010) \\
\hline $\begin{array}{l}\text { Curriculum content on Business } \\
\text { Ethics devised by ethics } \\
\text { specialists }\end{array}$ & $\begin{array}{l}\text { Can facilitate the integration of } \\
\text { sustainability into courses in a } \\
\text { relatively seamless manner }\end{array}$ & $\begin{array}{l}\text { Hartman and } \\
\text { Werhane (2009) }\end{array}$ \\
\hline \multirow[t]{2}{*}{$\begin{array}{l}\text { Add subject-specific } \\
\text { sustainability knowledge to an } \\
\text { existing module }\end{array}$} & $\begin{array}{l}\text { Focus on teaching students 'soft } \\
\text { skills' such as teamwork or } \\
\text { conceptualising 'the business case' } \\
\text { for sustainability }\end{array}$ & $\begin{array}{l}\text { Truscheit and Otte } \\
(2007)\end{array}$ \\
\hline & $\begin{array}{l}\text { Indicate the skills, attitudes, } \\
\text { competencies, dispositions and } \\
\text { values that are necessary for } \\
\text { surviving and thriving in the } \\
\text { declining conditions of the world in } \\
\text { ways which slowdown that decline as } \\
\text { far as possible }\end{array}$ & Stibbe (2009:10-11) \\
\hline
\end{tabular}

Table 2: Examples, challenges and opportunities of "Digging Deep".

\begin{tabular}{|l|l|l|}
\hline Digging Deep example & Challenges and opportunities & Source \\
\hline Use of optional modules with a & Uncomplicated technique for & Holt (2003) \\
focus on sustainability & $\begin{array}{l}\text { implementing sustainability but may } \\
\text { be perceived as 'add-on' }\end{array}$ & \\
\cline { 2 - 4 } & $\begin{array}{l}\text { Modules are unlikely to be selected } \\
\text { by the students who need them the } \\
\end{array}$ & Baden (2013) \\
& most & \\
\hline
\end{tabular}




\begin{tabular}{|l|l|l|}
\hline & May be useful if taught in depth and & (Goworek and \\
allows for specialization in certain & Molthan-Hill (2013) \\
areas & \\
\hline
\end{tabular}


Table 3: Examples, challenges and opportunities of "Mainstreaming".

\begin{tabular}{|l|l|l|}
\hline Mainstreaming example & Challenges and opportunities & Source \\
\hline Integrate sustainability into & May encompass integrating content & Rusinko (2010) \\
of sustainability-related tools & \\
\cline { 2 - 4 } & $\begin{array}{l}\text { Approach should go along with } \\
\text { emphasis on a broader cross- }\end{array}$ & Godemann et al \\
& curricular perspective ('soft skills') & \\
\hline $\begin{array}{l}\text { Offering students placements } \\
\text { within social enterprises or }\end{array}$ & Learn about social sustainability \\
from direct experience & (Baden, 2013) \\
\hline
\end{tabular}


Insert Table 4 here: Examples, challenges and opportunities of "Focusing".

\begin{tabular}{|c|c|c|}
\hline Focusing example & Challenges and opportunities & Source \\
\hline Set up a new programme & $\begin{array}{l}\text { Sustainability can be included across } \\
\text { the whole curriculum, adding } \\
\text { interdisciplinary perspectives }\end{array}$ & Roome (2005) \\
\hline \multirow[t]{5}{*}{$\begin{array}{l}\text { New (transdisciplinary) module } \\
\text { in all programmes }\end{array}$} & $\begin{array}{l}\text { Content and the students are from } \\
\text { different disciplines and can practise } \\
\text { in this group how to work in an } \\
\text { interdisciplinary way }\end{array}$ & Kurland et al (2010) \\
\hline & $\begin{array}{l}\text { A project-based learning module } \\
\text { setup enables both interdisciplinary } \\
\text { and cross-cultural learning }\end{array}$ & $\begin{array}{l}\text { Stubbs and Schapper } \\
(2011)\end{array}$ \\
\hline & $\begin{array}{l}\text { Students learn respect for other } \\
\text { disciplines though interdisciplinary } \\
\text { skills of both students and staff may } \\
\text { not always be present }\end{array}$ & Chhokar (2010) \\
\hline & $\begin{array}{l}\text { Business school curricula are } \\
\text { typically designed across functional } \\
\text { lines not interdisciplinary lines }\end{array}$ & Currie et al (2010). \\
\hline & $\begin{array}{l}\text { Business schools are too much } \\
\text { focused on well-designed problems } \\
\text { rather than 'messy' real-world } \\
\text { problems }\end{array}$ & Schoemaker (2008) \\
\hline
\end{tabular}


Table 5: Requirements for Systemic Institutional Integration

\begin{tabular}{|c|c|}
\hline $\begin{array}{l}\text { Requirements for Systemic Institutional } \\
\text { Integration }\end{array}$ & Source \\
\hline Systems thinking: & \\
\hline Systems thinking as a major building block & $\begin{array}{l}\text { Clayton and Radcliffe (1996); Stibbe } \\
\text { (2009), Baets and Oldenboom } \\
\text { (2009). }\end{array}$ \\
\hline Systemic leadership: & \\
\hline $\begin{array}{l}\text { Systemic leadership needed to empower change agents } \\
\text { across the entire institution }\end{array}$ & $\begin{array}{l}\text { Werhane and Painter-Morland (2011) } \\
\text { Painter-Morland (2008) }\end{array}$ \\
\hline Connectedness: & \\
\hline $\begin{array}{l}\text { Need to connect education to business, society and the } \\
\text { natural environment }\end{array}$ & $\begin{array}{l}\text { Leroy et al (2001); Courtice and Van } \\
\text { der Kamp (2013) }\end{array}$ \\
\hline $\begin{array}{l}\text { Capacity Building: } \\
\text { Empower institution members to effect change and } \\
\text { ensure a transformative social context }\end{array}$ & $\begin{array}{l}\text { Burchell et al (2015); Akrivou and } \\
\text { Bradbury-Huang (2011) }\end{array}$ \\
\hline
\end{tabular}


Table 6: ESGE-related modules in various business school programmes

\begin{tabular}{|c|c|c|c|}
\hline $\begin{array}{c}\text { Number of } \\
\text { ESGE integrated } \\
\text { Modules }\end{array}$ & Postgraduate Programmes & 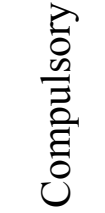 & $\frac{\stackrel{0}{0}}{\stackrel{0}{0}}$ \\
\hline \multirow{5}{*}{1 module } & Full-Time MBA & $66 \%$ & $24 \%$ \\
\hline & Part-Time MBA & $61 \%$ & $9 \%$ \\
\hline & General Masters & $61 \%$ & $16 \%$ \\
\hline & Specialised Masters & $51 \%$ & $17 \%$ \\
\hline & $\begin{array}{c}\text { Average on Postgraduate } \\
\text { Programmes } \\
\end{array}$ & $60 \%$ & $17 \%$ \\
\hline \multirow{5}{*}{ 2-4 Modules } & Full-Time MBA & $24 \%$ & $38 \%$ \\
\hline & Part-Time MBA & $30 \%$ & $57 \%$ \\
\hline & General Masters & $30 \%$ & $57 \%$ \\
\hline & Specialised Masters & $35 \%$ & $53 \%$ \\
\hline & $\begin{array}{l}\text { Average on Postgraduate } \\
\text { Programmes } \\
\end{array}$ & $30 \%$ & $51 \%$ \\
\hline \multirow{5}{*}{$\begin{array}{l}5 \text { or more } \\
\text { Modules }\end{array}$} & Full-Time MBA & $10 \%$ & $38 \%$ \\
\hline & Part-Time MBA & $9 \%$ & $34 \%$ \\
\hline & General Masters & $9 \%$ & $28 \%$ \\
\hline & Specialised Masters & $14 \%$ & $30 \%$ \\
\hline & $\begin{array}{c}\text { Average on Postgraduate } \\
\text { Programmes }\end{array}$ & $11 \%$ & $32 \%$ \\
\hline
\end{tabular}


Table 7: Training in sustainability-related skills

\begin{tabular}{|c|c|c|c|c|c|}
\hline \multirow{2}{*}{$\begin{array}{l}\text { Do you believe your institution } \\
\text { offers training to build } \\
\text { sustainability-related skills and } \\
\text { competencies to ... (question } 4.6 \text { of } \\
\text { the deans and } 4.8 \text { faculty, five } \\
\text { scales, from } 1 \text { to 5) }\end{array}$} & \multicolumn{2}{|c|}{ Deans } & \multicolumn{2}{|c|}{ Faculties } & \\
\hline & Average & STD & Average & STD & $\begin{array}{l}\text { T-test } \\
(\mathrm{p} \\
\text { value })\end{array}$ \\
\hline Tenured or Untenured Faculty & 3.23 & 1.018 & 2.83 & 1.431 & 0.02 \\
\hline Post-Doctoral or Adjunct Faculty & 3.22 & 1.058 & 2.83 & 1.475 & 0.03 \\
\hline $\begin{array}{l}\text { To Managerial \& Administrative } \\
\text { Staff }\end{array}$ & 3.32 & 0.948 & 2.83 & 1.496 & 0.03 \\
\hline
\end{tabular}


Figure 1: Matrix to illustrate integration of sustainability (adapted by Godemann et al, 2011, based on Rusinko, 2010)

\begin{tabular}{|c|c|c|}
\hline \multirow{2}{*}{ Narrow curricular } & Existing Structures & New Structures \\
\hline & $\begin{array}{l}\text { Quadrant } 1 \\
\text { Piggybacking } \\
\text { Integration of sustainability } \\
\text { within existing structures by adding } \\
\text { sustainability to individual sessions } \\
\text { of courses or modules }\end{array}$ & $\begin{array}{l}\text { Quadrant II } \\
\text { Digging deep } \\
\text { Integration of sustainability through } \\
\text { new stand-alone modules }\end{array}$ \\
\hline Broad curricular & $\begin{array}{l}\text { Quadrant III } \\
\text { Mainstreaming } \\
\text { Integration of sustainability } \\
\text { within existing structures but with } \\
\text { the emphasis on a broader cross- } \\
\text { curricular perspective (entire } \\
\text { curriculum) }\end{array}$ & $\begin{array}{l}\text { Quadrant IV } \\
\text { Focusing } \\
\text { Integration of sustainability through } \\
\text { new cross-disciplinary offerings } \\
\text { such as sustainability-related courses } \\
\text { which are required for all business } \\
\text { school students and new } \\
\text { programmes }\end{array}$ \\
\hline
\end{tabular}


Figure 2: Systemic Institutional Integration of ESGE issues into business schools

\begin{tabular}{|c|c|c|}
\hline & Existing Structures & New Structures \\
\hline Narrow curricula & $\begin{array}{l}\text { Practice } 1 \\
\text { Piggyback } \\
\text { Integration of sustainability within } \\
\text { existing structures by adding } \\
\text { sustainability to individual sessions } \\
\text { of courses or modules }\end{array}$ & $\begin{array}{l}\text { Practice II } \\
\text { Digging deep } \\
\text { Integration of sustainability through } \\
\text { new stand-alone modules }\end{array}$ \\
\hline Broad curricula & $\begin{array}{l}\text { Practice III } \\
\text { Mainstreaming } \\
\text { Integration of sustainability within } \\
\text { existing structures but with the } \\
\text { emphasis on a broader cross- } \\
\text { curricular perspective (entire } \\
\text { curriculum) }\end{array}$ & $\begin{array}{l}\text { Practice IV } \\
\text { Focusing } \\
\text { Integration of sustainability though } \\
\text { new cross-disciplinary offerings such } \\
\text { as sustainability related courses which } \\
\text { are required for all business school } \\
\text { students and new programmes }\end{array}$ \\
\hline Beyond curricula & \multicolumn{2}{|c|}{$\begin{array}{l}\text { Practice } V \\
\text { Systemic Institutional Integration } \\
\text { Integration of sustainability in existing and new core, cross-disciplinary } \\
\text { curricula, supported by a philosophy that influences all aspects of the } \\
\text { institution. It involves creating a systemic capability, distributed and nurtured } \\
\text { throughout the organization, which creates the impetus towards change in } \\
\text { students, faculty, administrators, the institution as a whole, as well as } \\
\text { organizations that hire its alumni. }\end{array}$} \\
\hline
\end{tabular}


Figure 3: Transition from Digging-deep to Focusing in average European postgraduate programmes

Digging deep vs. Focusing in average European postgraduate programmes

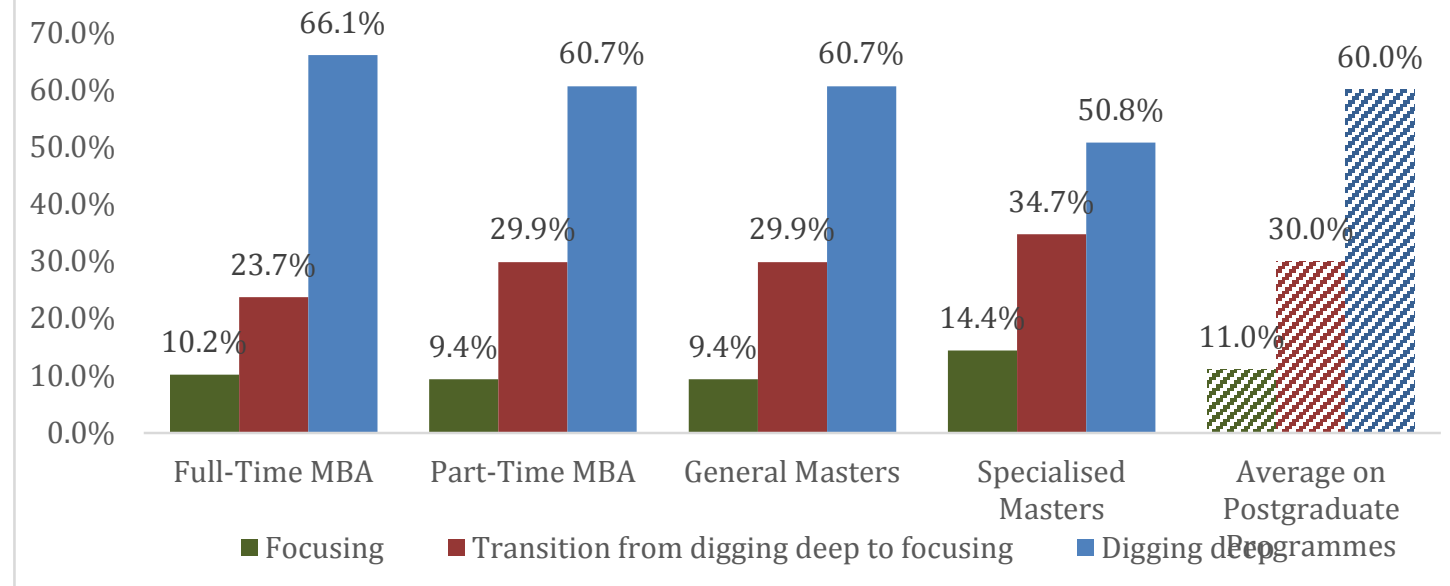

